\title{
A Model of Chemotherapy-Induced Tumor Dormancy: Doxorubicin Retention and Degradation Defines Resumed Growth in Vivo
}

Gintaras Zaleskis ( $\square$ gintaras.zaleskis@nvi.lt )

National Cancer Institute

Sima Garberytè

State Research Institute Centre for Innovative Medicine

Božena Pavliukevičienè

Vilnius University

Dainius Characiejus

State Research Institute Centre for Innovative Medicine

Karolina Žilionytè

National Cancer Institute

Jan Aleksander Kraśko

National Cancer Institute

Vitalijus Karabanovas

National Cancer Institute

Nijole Matuseviciene

National Cancer Institute

Vakare Barbora Kucinskaite

National Cancer Institute

Vita Pasukoniene

National Cancer Institute

\section{Research Article}

Keywords: Tumor dormancy, recurrence, chemotherapy, drug uptake, doxorubicin, tissue retention, anthracycline degradation

Posted Date: March 10th, 2021

DOI: https://doi.org/10.21203/rs.3.rs-256128/v1

License: (a) (i) This work is licensed under a Creative Commons Attribution 4.0 International License.

Read Full License 


\section{Abstract}

Background. Cancer recurrence after adjuvant chemotherapy with long periods of remission is common. After cessation of the therapy, the dormant cells may repopulate, but the signals that control the tumor to exit dormancy are not completely understood. We hypothesized that tissue bound cytotoxic drug indwelling in a body for years might somehow contribute to dormancy or recurrence of a tumor. The purpose of this study was to design a model demonstrating that viable cells implanted in mice can repopulate or be suppressed, depending on the cytotoxic preload conditions.

Methods. A two-step dormancy/recurrence (TSDR) murine model was designed, which mimics the extrusion of taken up drug from tumor cells. The viable cells preloaded with drug were implanted into mice. The survival rates of these mice were then used as criteria to demonstrate the relationship between resumed growth and drug cellular efflux/viability. The drug internalization patterns following their exposure to doxorubicin (dox) or degraded dox (dox-dgr) were investigated by exploring flow cytometry, spectral analysis, high performance liquid chromatography and confocal microscopy. Antiproliferative and myelotoxic capacity was evaluated by hematological nadir induced by the iv injected drug.

Results. The viable SL2 lymphoma cells exposed to $10 \mu \mathrm{g} / \mathrm{ml}$ of dox for $30 \mathrm{~min}$ and injected into syngeneic DBA/2 mice were made unable to recure. Exposure of cells to lower dox concentrations (0.01 $1.0 \mu \mathrm{g} / \mathrm{ml}$ ) resulted in tumor recurrence, similar to that which was observed during implantation of an untreated tumor. Dox-dgr kept at $37^{\circ} \mathrm{C}$ for 365 days lost its tumoricidal and antiproliferative capacity and displayed a loss of selectivity of nuclear fluorescence.

Conclusions. Our TSDR model is a rapid convenient tool to study in vivo behavior of cells preloaded with cytotoxic drug. This approach focuses on mechanisms of tumor cells exiting dormancy, in relation to cytotoxic drug efflux. Multiple modifications of our TSDR model are possible, including nude mice models. As an example, we used one-year body temperature exposed dox to demonstrate its inability to retain sufficient cytotoxic capacity.

\section{Background}

Residual tumor cells are detected in most cancer patients following surgical and adjuvant treatment (1). These residual cells might remain dormant for years before resuming proliferation and recurrence - the leading cause of cancer mortality $(2,3)$. A little known fact is that several anticancer drugs might also remain in the body for many years following successful chemotherapy. The most studied agents in this context are platinum compounds continuing to be present in blood and urine of patients treated more than 20 years ago (4). The long duration of tissue bound platinum was hypothesized to be related to late neurotoxicity, increased secondary cancer risk, tinnitus and some other side effects $(4,5)$. We hypothesized that prolonged presence of tissue bound cytotoxic drug might be associated with not only side effects, but also with dormancy prolongation. Interestingly, platinum excreted into plasma of patients was found to be pharmacologically active and retained some $10 \%$ of initial reactivity in ex vivo 
assays up to 3 years of body indwelling (6). Some indirect evidence of antitumor activity of tissue retained platinum is found in surgical specimens taken from patients who received preoperative chemotherapy. Patients with higher platinum concentration in a lung tumor had a longer time until recurrence and longer overall survival (7). Platinum was detectable in surgical specimens up to 72 days after preoperative chemotherapy and higher platinum content in tumors correlated with improved pathological response of gastric cancer (8). In fact, long term tissue presence was found in autopsy specimens of patients treated not only with platinum compounds. Different groups of cytotoxic drugs or their metabolites were also shown to exhibit long tissue persistence in autopsy specimens $(9,10,11)$. However, all of these studies were focusing primarily on the drug elicited side effects.

The majority of cytotoxic drugs are known to exhibit a high volume of distribution, short half-life in plasma and high tissue uptake following a single iv shot. Cancer chemotherapy obviously spares some malignant cells and the outcome of micrometastatic disease might be related to miniscule amounts of pharmacologically active drug located in tissues and cells. This tissue retained drug is exposed to multiple factors devaluing its antitumor activity: enzymes, $\mathrm{pH}$ fluctuations, reactive radicals, body temperature, etc. The complexity of these mechanisms and long duration of factor interplay is not easy to reproduce in an experiment and the subject has not yet been studied.

We developed an assay to demonstrate the role of cellular drug internalization on tumor recurrence rates. Viable SL2 lymphoma cells loaded with doxorubicin (dox) were exhibiting implantation and growth when implanted intraperitoneally (ip) into DBA/2 mice if the exposure dose was lower than $10 \mu \mathrm{g} / \mathrm{ml}$. Long term body temperature degraded dox lost its antiproliferative capacity, indicating that tissue retained drug might not be effective enough to assure tumor dormancy.

\section{Materials And Methods}

\section{Mice, tumors, cell line, drugs testing}

$D B A / 2$ mice, aged 8 to 12 weeks, were obtained from a local breeding facility SRICIM, Vilnius, Lithuania. Mice were used and cared for in accordance with the Guide for the Care and Use of Laboratory Animals. All research protocols were approved by the Institutional Animal Care Committee. Animals had ad libitum access to pelleted feed, food supplements and water. All animals were determined specific pathogen free. Dox or dox-dgr were injected iv via retroorbital plexus as a single push at a dose of $15 \mathrm{mg} / \mathrm{kg}$. Light inhalation anesthesia with isoflurane was used for iv injections and blood sampling procedures. The SL2 lymphoma occurred as a spontaneous tumor in a DBA/2 mouse of the Chester Beatty Research Institute, UK, and was acquired through prof. Den Otter, University Medical Center Utrecht, Netherlands. SL2 cells were maintained in RPMI-1640 medium (Thermo Fisher scientific, Waltham, USA) containing 10\% heatinactivated fetal bovine serum (Thermo Fisher scientific, Waltham, USA). All tumors in our TSDR study were induced by ip injection of $5 \times 10^{5}$ cells per mouse. The therapeutic efficacy of dox and dox-dgr was tested by injecting drug iv at specific time intervals ( $24 \mathrm{hr}, 48 \mathrm{hr}, 120 \mathrm{hr}, 168 \mathrm{hr}$ and $192 \mathrm{hr}$ ) following ip implantation of $5 \times 10^{4}$ cells on day 0 . 


\section{Drugs and reagents}

Doxorubicin hydrochloride ( $2 \mathrm{mg} / \mathrm{ml}$ ) (Ebewe, Unterach, Austria) was obtained from a hospital pharmacy. Daunorubicin hydrochloride (analytical grade), chloroform (HPLC grade). Acetonitrile, orthophosphoric acid and hydrochloric acid were purchased from Sigma Chemical Company (St Louis, MO, USA) and HPLC grade methanol was purchased from Carl Roth GmbH (Karlsruhe, Germany).

\section{Two step tumor dormancy/recurrence (TSDR) model}

The time course of dox-loaded viable SL2 cell ip implantation into DBA2 mice is shown in Fig 1. SL2 cells were cultured for $48 \mathrm{~h}$ to obtain $5 \times 10^{7}$ cells (viability $>95 \%$ ). Then the suspension was washed and incubated for 30 min. within RPMI-1640 medium containing $10 \%$ of fetal bovine serum (FBS) and variable amounts of dox or dox-dgr $(10 \mu \mathrm{g} / \mathrm{ml}, 1.0 \mu \mathrm{g} / \mathrm{ml}, 0.5 \mu \mathrm{g} / \mathrm{ml}, 0.1 \mu \mathrm{g} / \mathrm{ml}, 0.05 \mu \mathrm{g} / \mathrm{ml})$. Following 30 min. of incubation, the media containing dox or dox-dgr was washed with phosphate buffered saline (PBS) and put on ice before the transplantation procedure. Then SL2 dox loaded cells were diluted in PBS and a total of $5 \times 10^{5}$ cells per mouse (inoculation volume $0.2 \mathrm{ml}$, viability $>95 \%$ ) were injected ip. The viable cell number was determined by performing trypan blue stains on the cells. Control mice received the same number of cells exposed to RPMI-1640 medium containing no dox. Total time of the manipulation procedure from cell harvesting to inoculation into mice did not exceed 60 min. The number of surviving mice in each experimental group was checked daily until day 30 , then checked twice a week until day 60 . All mice that died had an evident ascitic tumor. Mice surviving more than 60 days were considered as cured.

\section{Immunophenotyping}

SL2 cells were centrifuged at $300 \mathrm{~g}$ for $5 \mathrm{~min}$ at $20^{\circ} \mathrm{C}$ and washed twice with FACS buffer (BectonDickinson, San Jose, CA, USA). For flow cytometry (FCM) analyses, $1 \times 10^{6}$ cells per sample were incubated with FACS buffer containing $0.1 \mu \mathrm{g}$ of anti-mouse Fcglll/II receptor (clone 2.4G2) for 20 min at $4^{0} \mathrm{C}$. Cells were then washed with FACS buffer and staining was performed using $0.4 \mu \mathrm{g}$ APC anti-CD3 (clone 17A2), $0.5 \mu \mathrm{g}$ of FITC anti-CD4 (clone GK1.5), $0.5 \mu \mathrm{g}$ of PerCP anti-CD8a (clone 53-6.7), $0.02 \mu \mathrm{g}$ of PE anti-CD44 (clone IM7), $2 \mu \mathrm{g}$ of Pacific blue anti-CD45 (clone 30-F11). All antibodies were purchased from Thermo Fisher scientific (Waltham, USA). Cells were stained at $4{ }^{\circ} \mathrm{C}$ for $30 \mathrm{~min}$ and then washed with FACS buffer. At least 10,000 cells were acquired on a FACS-LSRII flow cytometer (Becton-Dickinson, San Jose, CA, USA) and analysis was performed using FlowJo 8.6.3 software (Tree Star, Ashland, OR, USA).

\section{Flow cytometry analysis for dox and dox-dgr uptake}

Cells loaded with dox or dox-dgr were washed for 30 min. twice with PBS and resuspended in $1.0 \mathrm{ml}$ of PBS. Fluorescence histograms were then recorded with a FACS LSRII flow cytometer (Beckton Dickinson, San Jose, USA) in FL2 channel with $488 \mathrm{~nm}$ excitation. Mean channel fluorescence intensity (FL 2 height) 
was used as an uptake value. Non-viable cells and duplets were excluded by gating out their light scatter characteristics. A total of 20,000 events to generate each histogram were acquired.

\section{Confocal microscopy and spectral analysis}

Following exposure to dox and dox-dgr, SL2 cells suspended in PBS were made adherent to glass coverslips placed at the bottom of a 12-well culture plate (TPP AG. Trasadingen, Switzerland) via 30 min. of gravity sedimentation as described by Tsang et al. (12). Adhered cells were fixed in $4 \%$ paraformaldehyde and then analyzed. The localization of dox and dox-dgr in SL2 cells were analyzed under a confocal microscope (Nikon Eclipse TE2000-S, C1 plus, Nikon, Tokyo, Japan) by scanning with the argon ion laser ( $488 \mathrm{~nm}$ ) using oil immersion 60× NA 1.4 objective (Plan Apo VC, Nikon, Japan). Brightfield microscopy was performed to visualize morphology of the cells. The fluorescence of dox and dox-dgr was detected using a 515/30 bandpass filter (Semrock Inc., USA). In addition, spectrally-resolved intracellular fluorescence of dox and dox-dgr was registered using a microscope 32-channel spectral imaging unit. The fluorescence spectra of dox and dox-dgr in single cells and subcellular regions was analyzed. In the region of interest (ROI) in the stacked confocal images, cell fluorescence was measured. The images were further processed using EZ-C1 v3.91 (Nikon, Japan) and ImageJ v1.53a software (NIH, USA).

\section{Optical characterization}

Steady-state absorption and fluorescence spectra of doxorubicin in PBS were measured with a singlebeam spectrophotometer Varian Cary Win UV (Varian Inc., Australia) and spectrofluorometer (FLS920, Edinburgh Instruments, Livingston, UK). Polystyrene cuvettes with an optical path length of $1 \mathrm{~cm}$ were used for all measurements.

\section{Blood sampling, plasma preparation, complete blood counts}

Blood samples $(125 \mu \mathrm{L})$ were taken from the retroorbital plexus before and after the dox administration at several time points $5 \mathrm{~min}, 15 \mathrm{~min}, 30 \mathrm{~min}, 60 \mathrm{~min}, 6 \mathrm{hr}, 12 \mathrm{hr}, 48 \mathrm{hr}$ and $72 \mathrm{hr}$ in tubes containing EDTA as an anticoagulant. Dox-dgr measurements were not performed due to imprecision of the procedures (presence of byproducts with HPLC retention times close to dox and overlapping with internal standard). Blood sampling and dox injection were performed on two contralateral retroorbital plexus, while isoflurane anesthesia was applied. Each blood sample was gently inverted several times to ensure complete mixing with the anticoagulant. After centrifugation at $5000 \mathrm{x} \mathrm{g}$ for $10 \mathrm{~min}$, plasma samples were separated and stored at $-20^{\circ} \mathrm{C}$ until analysis. Complete blood counts (CBC) were analyzed using ABX Micros ESV 60 within an hour of sampling.

\section{Pharmacokinetics}

The microvolume method (13) was applied in this study for plasma Dox analysis. $50 \mu \mathrm{L}$ of internal standard solution ( $800 \mathrm{ng} / \mathrm{mL}$ Daunorubicin hydrochloride) was added to $60 \mu \mathrm{L}$ of a plasma sample and vortex-mixed for 30 seconds. The extraction of the drug was performed by adding $900 \mu \mathrm{L}$ of a 
chloroform/methanol mixture (4:1, v/v). After vortex mixing for $10 \mathrm{~min}$ and centrifugation (10 min, 10,000 $\mathrm{x} \mathrm{g}$ ), the organic phase was collected, transferred to a clean tube, then evaporated to dryness under a stream of nitrogen. Dry residue from the plasma was dissolved in $60 \mu \mathrm{L}$ of mobile phase, and after centrifugation for $5 \mathrm{~min}(10,000 \mathrm{xg})$, injected into the chromatographic column. The area under the concentration curve (AUC) were calculated by trapezoid rule.

\section{Chromatographic conditions}

High performance liquid chromatography (HPLC) analysis was performed on a Perkin Elmer system that consisted of a Flexar binary LC pump, a Kit - Flexar 3 CHNL VAC degasser, a Flexar LC autosampler and Flexar fluorescence detector (Xenon lamp). The chromatography data was acquired by Chromera software from Perkin Elmer. The chromatography separation was performed on a Brownlee Bio C18 column ( $4.6 \times 150 \mathrm{~mm}, 5 \mu \mathrm{m}$ particle size, Perkin Elmer, Shelton, USA). The optimum mobile phase consisting of acetonitrile and water $(32: 68, \mathrm{v} / \mathrm{v})$, was $\mathrm{pH}$ adjusted to 2.6 with $85 \%$ orthophosphoric acid. Samples were delivered via isocratic flow at a rate of $0.25 \mathrm{~mL} / \mathrm{min}$. The column temperature was maintained at $37^{\circ} \mathrm{C}$ and excitation and emission wavelengths were set at 475 and $555 \mathrm{~nm}$ respectively. The injection volume was $50 \mu \mathrm{L}$.

\section{Statistical analysis}

The statistical tests were performed using STATISTICA 12.0 (TIBCO Software Inc Palo Alto, California, USA).

All the results are presented as means and standard error (mean \pm S.E.). Significance was considered at values of $p<0.05$.

\section{Results}

The characteristics of the SL2 cell line used in our TSDR model are presented in Table 1. We have chosen to use SL2 lymphoma line syngeneic to DBA2 mice to investigate the relationship between dox uptake and tumor dormancy control in vivo. The rationale for choosing SL2 lymphoma was the following: 1) sensitivity to dox in vivo and in vitro, 2) exact range of dox vs tumor size shows therapeutic effectiveness i.e. cure (small tumors) and recurrence (medium or large tumors), 3) specific immunophenotype allowing minimal residual disease monitoring in ascite samples, 4) suspension type of growth in vitro, allowing to quantitatively analyze dox uptake by FCM without detachment, trypsinization or additional manipulation. This is of particular importance when exploring our TSDR model and attempting to shorten manipulation time. Short high dose exposure helps to keep high and comparable cell viability values before and after dox loading. In addition, adherent subtypes of identical cell lines growing in suspension might exhibit significant variability of dox resistance (14). The SL2 lymphoma belongs to the T cell lineage and was reported to express Thy $1.2(15)$. The SL2 line explored in our TSDR model maintained its T cell specificity with CD3+4-8+44+45+ immunophenotype. This phenotype alongside FCM light scatter characteristics, permits tumor cell distinction in ascites samples with high host cell admixtures. 
Chemotherapy simulation in vitro is usually experimented with drug exposure for several days $(16,17)$. We preferred to simulate the short initial (distribution) pharmacokinetic phase since the uptake in vivo is mostly related to it. The second phase of biexponential elimination curve is more attributable to a dox tissue efflux rather than the uptake. We attempted to modify already reported dormancy/recurrence model (16) by significantly shortening the exposure duration and by implanting cells into mice rather than returning them to a cell culture (schematic of our TSDR model shown in Fig 1). The lowest effective dox concentration continuously imitating the dormancy in vivo was $10 \mu \mathrm{g} / \mathrm{ml}$ (Fig 1). To further investigate how this concentration compares to plasma dox content, we performed pharmacokinetic analysis of dox injected iv Unexpectedly, maximal plasma dox concentration was never reaching the $10 \mu \mathrm{g} / \mathrm{ml}$ (Fig 2) needed for efficient in vivo tumor dormancy effect $\left(C_{\max }\right.$ was $\left.1.33 \mu \mathrm{g} / \mathrm{ml}\right) . \mathrm{AUC}_{0-0.5}$ during in vitro dox loading was $5.0(\mu \mathrm{g} \cdot \mathrm{h} / \mathrm{ml})$ whereas plasma $A U_{0-72}$ of iv injected dox was $3.6(\mu \mathrm{g} / \mathrm{ml} \cdot \mathrm{h})$. Failure of doxdgr to affect any hematopoietic cell was observed comparing HGB, WBC and PLT counts in all three animal groups (control, receiving dox or dox-dgr). Dox induced a dramatic leukopenia as WBC counts decreased significantly from $7.7 \pm 0.59 \mathrm{k} / \mu \mathrm{l}$ to $2.6 \pm 0.42 \mathrm{k} / \mu \mathrm{l}$. Dox-dgr did not retain the capability to induce leukopenia (WBC counts were $7.1 \pm 1.4 \mathrm{k} / \mu \mathrm{l}, \mathrm{p}=0.4$ ).

Tissue retention of cytotoxic drug is known to persist for several years. To simulate long term tissue indwelling of dox, we incubated the drug at $37^{\circ} \mathrm{C}$ in darkness in the original vial (sterile) for a period of 365 days. Body temperature induced drug decay was analyzed by HPLC and by spectrometry following 120 days (medium term) and 365 days (long term) exposure at $37^{\circ} \mathrm{C}$. The characteristics of dox-dgr are summarized and compared to fresh dox in Table 2. The broadening of the main absorption band with significant hypochromism in the spectral region between $415 \mathrm{~nm}$ and $540 \mathrm{~nm}$, and a weak hyperchromism in the spectral region above $540 \mathrm{~nm}$, is an absorbance modification of dox-dgr which occurred during storage for the medium- and long-term periods at $37^{\circ} \mathrm{C}$ (spectrum presented in supplemental material). The observed absorbance modification and significant loss of fluorescence intensity in aqueous solutions resembles characteristics of aggregation and/or dimerization of dox (18). The fluorescence spectra of dox and dox-dgr were also compared in samples of the aqueous solution and in the nucleus of drug loaded SL2 cells. Presence of nuclear dox or dox-dgr determined by confocal ROI analysis exhibited fluorescence with spectral characteristics, defined by three distinct peaks similar to the aqueous solution spectra of both drugs (Fig 3, A and B). However, the dramatic quantitative reduction of dox related fluorescence was seen in the aqueous solution of dox-dgr, when compared to dox samples (Fig $3 \mathrm{C}$ ). The HPLC analysis of the aqueous solutions of dox-dgr revealed that the characteristic dox peak is significantly reduced compared to dox sample (Fig. $3 \mathrm{D}$ ), but still noticeable and exhibits a retention time similar to some byproducts. (Fig $3 \mathrm{E}$ and F). The uptake of dox-dgr resulted in dim but still detectable fluorescence in SL2 cells after in vitro drug load before proceeding with second in vivo step of TSDR procedure (Fig 4 a-c compared to Fig 4 d-f). The nuclear fluorescence intensity measured by confocal microscopy in regions of interest (ROI) were significantly lower in dox-dgr samples when compared to fresh dox samples. Notably, dead/apoptotic cell presence showed hyperchromatism of nuclear fluorescence due to the dox-dgr (Fig $4 \mathrm{~g}-\mathrm{i}$ ), which is known to be a feature of fresh dox in permeable cells. The dim dox-dgr fluorescence lost its nuclear selectivity in viable cells and was found to 
be homogenously distributed between their cytoplasm and nucleus. The dox-dgr also lost its capability of inducing a myelotoxic (antiproliferative) effect after iv injection compared to dox (Fig 2).

\section{Discussion}

In this study we used dox, a mainstream chemotherapeutic agent, which is inherently fluorescent, as a model drug to demonstrate its cellular uptake significance in our TSDR model. Dox is known to enter a cell, intercalate to DNA and block topoisomerase II. The cell's ability to proliferate is then strictly conserved to a number of intracellular dox molecules attained by DNA (19). The question is if this intracellular drug indwelling in tissues for years (and recycling locally) can keep controlling a minimal residual disease. For more than five decades, dox is widely used as a front-line therapy for several different malignancies. However, its role in controlling residual micrometastatic diseases (if any) is not completely understood. Chemotherapy does not only spare some viable tumor cells but also results in a long tern tissue persistence of injected drug. The cellular bound drug and its active metabolites definitely undergo some gradual transformation while indwelling in tissues. The characteristic feature of this transformation and its effect on tumor and host tissue is not studied. It can feature decreased or increased antitumor (and dormancy maintaining) activity. Our dox-dgr samples showed obvious visual change but we analyzed only some of its physicochemical properties. Spontaneous aggregation of dox is known to induce a decrease of the fluorescence quantum yield attributed to the formation of nonfluorescent dimers (18) Self-association is a process that competes with binding to DNA and formation of hetero complexes $(18,27)$.

Tumor cells loaded with dox following exposure to $10 \mu \mathrm{g} / \mathrm{ml}$, lost their ability to resume proliferation in DBA/2 mice when injected IP. Exposure of cells to lower doses of dox did not result in any recurrence delay. The SL2 cell viability (> $90 \%$ ) after dox exposure of all samples before their ip implantation in mice was sufficient to produce tumors. As little as 100 cells were reported to be enough to result in ascitic SL2 lymphoma growth and kill the mice (15). The rate of proliferation and aggressiveness of SL2 line is notable: the growth fraction of an SL2 tumor on day 4 after implantation is $79.2 \%$ (20). So just one viable cell out of each 5000 cells implanted ( $0.02 \%$ viability) should have been sufficient enough to assure tumor formation and growth. We hypothesized that gradual extrusion of dox from the tumor cells should have resulted in the tumor escaping from the dormancy state attained after the initial drug cellular accumulation. A tumor exposed to $10 \mu \mathrm{g} / \mathrm{ml}$ dox for $30 \mathrm{~min}$, was empirically determined to be sufficient enough to stop tumor proliferation. Subsequently, a pharmacokinetic study was conducted to clarify how this exposure (in terms of dox concentration and AUC) compares to plasma dox concentration detectable after a $15 \mathrm{mg} / \mathrm{kg}$ dox injection. The highest plasma dox concentration was reached at 5 minutes post injection, and was only $1.33 \mu \mathrm{g} / \mathrm{ml}$. It might be questionable if our TSDR model is relevant to an in vivo animal or clinical conditions. That is because we failed to demonstrate that maximum plasma dox concentration ever reached $10 \mu \mathrm{g} / \mathrm{ml}$ in mice following a high dose of dox administration. However, several facts are to be taken into consideration: 1) tissue and cells in mice following the injection were exposed to detectable dox plasma levels considerably longer than $30 \mathrm{~min}$; dox in the plasma of treated DBA/2 mice was detectable for at least $72 \mathrm{hr}$, whereas in vitro exposure conditions lasted just $30 \mathrm{~min}, 2$ ) 
the $A \mathrm{CC}_{0-0.5}$ of TSDR model exposure was $5.0(\mu \mathrm{g} \cdot \mathrm{h} / \mathrm{ml})$ whereas $\mathrm{AUC}_{0-72}$ of dox in mice plasma following a $15 \mathrm{mg} / \mathrm{kg}$ iv. injection was $3.6(\mu \mathrm{g} \cdot \mathrm{h} / \mathrm{ml})$; the same exposure dose $(10 \mu \mathrm{g} / \mathrm{ml})$ can be compared to dox uptake investigations done by others; For instance the duration of $10 \mu \mathrm{g} / \mathrm{ml}$ exposure of 5 days was reported $(17)$; 4 ) apparently, the short tissue exposure to dox is more relevant to clinical situations than AUC (21),5) the sufficient cellular uptake of dox is already seen following $5 \mathrm{sec}$ of exposure and might play a role in tumor growth control (22). It is technically impossible to test if, at a 5 sec time interval, the plasma levels are or are not reaching $10 \mu \mathrm{g} / \mathrm{ml}$ following dox iv administration. The max plasma concentration in humans was found to be in the vicinity of $1-4 \mu \mathrm{g} / \mathrm{ml}$ after the administration of common therapeutic doses (23). However, major exposure of cells and tissue to dox in humans is found in the terminal elimination phase where plasma concentrations are around $0.05 \mu \mathrm{g} / \mathrm{ml}$ and continues to persist for at least $48 \mathrm{hr}$ (25). Not only dox, but also its active metabolites, are found in significant amounts in human plasma and are contributing to its antiproliferative effects.

The take up of dox as well as a majority of other cytotoxic drugs tend to be retained in tissues for months and years. The accidentally extravasated dox was found to be present in significant amounts in tissue adjacent to the extravasation site for 5 months (25). Tissue uptake of dox is hundreds of times higher than the maximum plasma concentration (26). We expected that dox-dgr can partly simulate the tissue indwelling of dox and should have retained some antiproliferative capacity. The short term (21 day) dox $37^{\circ} \mathrm{C}$ exposure did not reveal any absorbance or fluorescence spectrum alteration in an aqueous solution or cellular nuclei (data not shown). However, at medium term (120 days), the exposure to dox-dgr lost its antiproliferative capacity and was not capable of inhibiting tumor cell recurrence in our TSDR model. Upon HPLC analysis, the residual dox peak was still noticeable, although it exhibited significant quantitative decline. The SL2 cells prepared for IP injection revealed identical intracellular fluorescence spectra for dox and dox-dgr as judged by confocal microscopy. Fluorescence intensity and uptake patterns however, were dramatically altered in dox-dgr exposed samples as compared to fresh dox samples. There was no preferential nuclear accumulation in samples exposed to dox-dgr, which was a characteristic feature of fresh dox uptake. This raises the question if nuclear dox binding capacity is not undergoing transformation following long term body indwelling of a drug. In fact, cellular binding patterns might have a direct link to dox's therapeutic efficacy. For instance, dox cytotoxicity in a clonogenicity assay was shown to be highly dependent on cellular accumulation patterns (28). Internalized tightly bound cellular dox was the only active form of drug eliciting cytotoxic effects, as reported in this study. The tightly bound dox was not very prone to outward efflux. However, $90 \%$ of intracellular dox could be attributed to a loose bound category demonstrated in this investigation.

Dox is known to enter the cell by passive diffusion, but at lower concentrations much of it is taken up rapidly by high-affinity binding sites (29). At higher concentrations, these binding sites are saturated and additional drug taken up by the cell remains unbound in the intracellular space. It is not clear if this intracellular unbound dox can play the role of lose bound fraction and be prone to a rapid extrusion upon IP implantation in our TSDR model. 
Our findings might be questioning the supposition that long term control of micrometastatic disease is elicited through direct antitumor effects of cellular bound drug. Our assumption is based upon the fact that long term simulation of indwelling drug failed to demonstrate residual antiproliferative activity. However, this does not rule out the possibility that tissue bound weakened dox is still involved in suppressing tumor regrowth at least for several months following discontinuation of chemotherapy. This temporal effectiveness of dormancy control may alter the tumor microenvironment and activate some other host mediated tumor control mechanisms (i.e. immune surveillance). Other cytotoxic drugs, such as platinum, were shown to retain antiproliferative capacity for up to 3 years following iv therapy (6). Our findings do not rule out the possibility that some marginal antiproliferative capacity of dox-dgr was still preserved. The WBC nadir assay of dox (15 mg/kg, iv) revealed a dramatically higher antiproliferative capacity for fresh dox compared to the dox-dgr. However, the relative weakness of dox-dgr in this assay might simply be due to a smaller amount of active dox fraction within a whole dox-dgr vial. The HPLC analysis demonstrated that dox-dgr retains only $16.8 \%$ of the initial dox amount after 120 days at $37^{\circ} \mathrm{C}$. This means the $15 \mathrm{mg} / \mathrm{kg}$ of dox-dgr would correspond to roughly $2.5 \mathrm{mg} / \mathrm{kg}$ of fresh dox. Interestingly, $2.5 \mathrm{mg} / \mathrm{ml}$ of fresh dox injected iv into DBA2 mice did not show significant WBC decline at a 48 hour time point (data not shown). Even fresh dox tends to form pharmacologically inactive dimers in a vial at room temperature. Some $47 \%$ of the fresh dox can be attributable to these spontaneously forming byproducts $(18,25)$. We cannot rule out the possibility that DNA bound dox might retain even more antiproliferative capacity than the dox kept at body temperature in the original vial. In theory DNA intercalated dox molecules should not be forming inactive aggregates in vivo.

Dox was rather extensively studied in the models of forced degradation under the conditions of hydrolysis (water, acid and alkali), peroxide oxidation, dry heat (short duration at $80^{\circ} \mathrm{C}$ ), photolysis and microwave irradiation $(29,30)$. To our knowledge, our study is the first to report on the degradation of dox stored at body temperature for the duration of 365 days. We were not specifically identifying the byproducts related to the dox decay, we instead tested the antitumor and myelotoxic properties of a whole dox-dgr product.

The dormancy/recurrence model developed by others with SU159 cells (16) explored a lower dox concentration $(0.5 \mu \mathrm{g} / \mathrm{ml})$ than ours. However, substantially longer exposure time ( $96 \mathrm{hr}$ ) was used to demonstrate dormancy in vitro. This can be converted into $A^{-} C_{0-96} 48 \mu \mathrm{g} / \mathrm{ml}$ which is significantly higher than the one used in our DTSR model. Interestingly this duration of exposure of dox with SU159 cells was considered to be short. Notably, the maximum plasma concentration of dox results in a peak concentration higher than $1.0 \mu \mathrm{g} / \mathrm{ml}$ in humans (23). In the model proposed by El-Kareh et al. (21), the dox mediated cell kill was demonstrated to be dependent on the peak concentrations rather than the time integral of concentration. We hypothesized that $96 \mathrm{hr}$ in vitro exposure (16) might not entirely duplicate the in vivo situation where dox plasma levels are barely detectable. The in vitro model is for cells in culture, where oxygenation, $\mathrm{pH}$, cell density, extracellular dox clearance, drug metabolism in liver and elimination in bile or urine are generally different than conditions in vivo. An empirically determined short exposure procedure which was blocking successful tumor implantation can help to better understand the 
mechanisms of local cytotoxic drug effects. For instance, dox at a dose of $1000 \mu \mathrm{g} / \mathrm{ml}$ for $60-120 \mathrm{~min}$ is used by intravesical instillation for the treatment of superficial bladder carcinoma. This is a 100 times higher concentration than explored in our study. In addition, the intravesical instillation is sometimes repeated with an interval of 1 week to 1 month, depending on whether the treatment is therapeutic or prophylactic. A local injection at the maximum safe dose of dox $(1000 \mu \mathrm{g}$ in the upper lid and $1500 \mu \mathrm{g}$ in the lower lid) was used for the treatment of blepharospasm (31). The cumulative dose in this study was even higher $-4000 \mu \mathrm{g}$ of dox per lid. Local implantable surgical devices, such as biodegradable mesh, are occasionally patented to claim therapeutic efficacy of anticancer drugs including dox (34). A dose of $10 \mu \mathrm{g} / \mathrm{ml}$ for $30 \mathrm{~min}$ definitely remains in the safe zone for a vesicant drug such as dox when applied locally. The effective concentration of dox or any other cytotoxic drug can be additionally investigated with the help of our TSDR model. Dox controlled release via biodegradable ureteral stent (35) is an example where this model could be explored for a rapid pre-screening to determine an effective concentration range for local use.

The idea that long term tumor exposure to suboptimal doses is breeding genetically resistant cells is just one of the popular premises. This assumption is based mostly on experiments in vitro. It is a well-known fact that resistant lines can be continuously passed in media containing a cytotoxic drug and losing no proliferative capacity. The resistance in humans is not necessarily mimicking this effect. Drug intracellular presence is the most obvious feature currently known to restrain cells from resumed proliferation. Notably, the primary resistance in humans and laboratory animals might be explained for instance by inoculum effect (36) or abundance of tumor cells (37). Multiple other non-genomic resistance factors were described: non-genetic plasticity (38), drug gradients in relation to blood vessels (39), regions of hypoxia (40), specificities of an extracellular matrix (41), abnormalities of tumor vascularization (42), and an abundance of cellular debris (43). All of these conditions are not easy to replicate in models relevant to clinical conditions. Our TSDR model is an attempt to elucidate one of the aspects of primary resistance and dormancy, which is the link between tissue retained drug and tumor recurrence.

\section{Conclusion}

The TSDR model is a rapid convenient tool to study in vivo behavior of cells preloaded with cytotoxic drug. This approach focuses on mechanisms of tumor cells exiting dormancy, in relation to cytotoxic drug efflux. The one-year body temperature exposed doxorubicin did not retain sufficient cytotoxic capacity as compared to fresh doxorubicin. Exploration of in vivo model for drug extrusion analysis reveals additional potentials to study drug tissue indwelling role in dormancy.

\section{Abbreviations}

dox: doxorubicin

dox-dgr: degraded doxorubicin (body temperature exposed long term) 
TSDR: two step dormancy recurrence

iv: intravenous

ip: intraperitoneal

FCM: flow cytometry

HPLC: high performance liquid chromatography

ROI: region of interest

$C B C$ : complete blood counts

AUC: area under the concentration curve

FBS: fetal bovine serum

dau: daunorubicin

HGB: hemoglobin

WBC: white blood cells

PLT: platelets

PBS: phosphate-buffered saline

\section{Declarations}

\section{Ethics approval and consent to participate}

Mice were used and cared for in accordance with the Guide for the Care and Use of Laboratory Animals. All research protocols involving animals were approved (approval permission number G2-120) by the Institutional Animal Care Committee, Vilnius, Lithuania (Valstybine Maisto ir Veterinarijos Tarnyba, Vilnius). The study was carried out in compliance with the ARRIVE guidelines.

\section{Consent of publication}

Not applicable.

\section{Availability of data and materials}

The datasets used and/or analyzed during the current study are available from the corresponding author on reasonable request. 
The authors declare that they have no competing interests.

\section{Funding}

This work was supported by grants from the Lithuanian Research Council, No KD-17027 .

\section{Authors' contributions}

GZ and SG participated in the study design, carried out all experiments and drafted the manuscript. BP performed HPLC analysis. DCh, KZ and JAK assisted in cell handling, flow cytometry and drug loading experiments. VK and SG performed spectral analysis and confocal imaging. VBK and NM participated in dissection of mice, sample collection and blood CBC analysis. JAK and VP performed the statistical analyses. VP conceived the study and helped to revise the manuscript. All authors read and approved the final manuscript.

\section{Acknowledgements}

We thank Ms. Jurgita Juršènaite in her assistance with cell culturing and cryopreservation. We also thank Mr. Bret Andrew Hudson for manuscript editing and revision.

\section{References}

1. Klein CA. Framework models of tumor dormancy from patient-derived observations. Curr Opin Genet Dev. 2011;21:42-9.

2. Sosa MS, Bragado P, Aguirre-Ghiso JA. Mechanisms of disseminated cancer cell dormancy: an awakening field. Nat Rev Cancer. 2014;14:611-22.

3. Risson E, Nobre AR, Maguer-Satta V, Aguirre-Ghiso JA. The current paradigm and challenges ahead for the dormancy of disseminated tumor cells. Nat Cancer. 2020; 1: 672-80.

4. Hjelle LV, Gundersen POM, Hellesnes R, Sprauten M, Brydoy M, Tanstad T et al. Long-term serum platinum changes and their association with cisplatin-related late effects in testicular cancer survivors. Acta Oncologica (Stockholm, Sweden). 2018; 57:1392-1400.

5. Hohnloser JH, Schierl R, Hasford B, Emmerich B. Cisplatin based chemotherapy in testicular cancer patients: long term platinum excretion and clinical effects. Eur J Med Res. 1996;1:509-14.

6. Brouwers EE, Huitema AD, Beijnen JH, Schellens JHM. Long-term platinum retention after treatment with cisplatin and oxaliplatin. BMC Clin Pharmacol. 2008; 8: 1-10.

7. Kim ES, Lee JJ, He G, Chow CW, Fujimoto J, Kalhor N, et al. Tissue platinum concentration and tumor response in non-small-cell lung cancer. J Clin Oncol. 2012;30:3345-52.

8. Cao Y, Chang Q, Cabanero M, Zhang W, Hafezi-Bakhtiari S, Hedley D, et al. Tumor platinum concentrations and pathological responses following cisplatin-containing chemotherapy in gastric cancer patients. J Gastrointest Cancer. 2019;50:801-7. 
9. Stewart DJ, Grewaal D, Green RM, Mikhael N, Goel R, Montpetit VA, et al. Concentrations of doxorubicin and its metabolites in human autopsy heart and other tissues. Anticancer Res. 1993;13:1945-52.

10. Stewart DJ, Grewaal D, Redmond DM, Mikhael NZ, Monipetit VAJ, Goel R, at alHuman autopsy tissue distribution of the epipodophyllotoxins etoposide and teniposide. Cancer Chemother. Pharmacol.1993: 32

11. Stewart DJ, Green RM, Mikhael NZ, Montpetit V, Thibault M, Maroun JA. Human autopsy tissue concentrations of mitoxantrone. Cancer Treat Rep. 1993;70:1255-61

12. Tsang M, Gantchev J, Ghazawi FM, Litvinov IV. Protocol for adhesion and immunostaining of lymphocytes and other non-adherent cells in culture. Biotechniques. 2017: 63:230-3.

13. Daeihamed M, Haeri A, Dadashzadeha S. Simple and sensitive HPLC method for fluorescence quantitation of Doxorubicin in micro volume plasma: applications to pharmacokinetic studies in rats. Iran J Pharm Res. 2015; 14 (Suppl.): 33-42.

14. Kraus AC, Ferber I, Bachmann SO, Specht $\mathrm{H}$, Wimmel A, Gross MW, et al. In vitro chemo- and radioresistance in small cell lung cancer correlates with cell adhesion and constitutive activation of AKT and MAP kinase pathways. Oncogene. 2002;21:8683-95.

15. Dullens HF, Hilgers J, Spit BJ, De Heer E, De Weger RA, Van Basten CD, et al. Staging, growth properties and metastatic behaviour of a transplantable murine T-cell lymphoma. Int $\mathrm{J}$ Tissue React. 1982;4:15-25.

16. Li S, Kennedy M, Payne S, Kennedy K, Seewaldt VL, Pizzo SV, et al. Model of tumor dormancy/recurrence after short-term chemotherapy. PLoS One. 2014;9:e98021.

17. Eom, YW, Kim M, Park S, Goo MJ, Kwon HJ, Sohn S et al.Two distinct modes of cell death induced by doxorubicin: apoptosis and cell death through mitotic catastrophe accompanied by senescence-like phenotype. Oncogen. 2005;24:4765-77.

18. Changenet-Barret P, Gustavsson T, Markovitsi D, Manet I, Monti S. Unravelling molecular mechanisms in the fluorescence spectra of doxorubicin in aqueous solution by femtosecond fluorescence spectroscopy. Phys Chem Royal Soc Chem. 2013;15:2937-44.

19. Maass KF, Kulkarni C, Quadir MA, Hammond PT, Betts AM, Wittrup KD. A Flow Cytometric Clonogenic Assay Reveals the Single-Cell Potency of Doxorubicin. J Pharm Sci. 2015;104:4409-16.

20. Eidukevicius R, Characiejus D, Janavicius R, Kazlauskaite N, Pasukoniene V, Mauricas M. et al. A method to estimate cell cycle time and growth fraction using bromodeoxyuridine-flow cytometry data from a single sample. BMC Cancer. 2005; 5:122.

21. El-Kareh AW, Secomb TW. Two-mechanism peak concentration model for cellular pharmacodynamics of doxorubicin. Neoplasia. 2005;7:705-13.

22. Skovsgaard T. Carrier-mediated transport of daunorubicin, adriamycin, and rubidazone in Ehrlich ascites tumour cells. Biochem Pharmacol. 1978;27:1221-7.

23. Fawehinmi, F. Pharmacokinetics of Doxorubicin in cancer chemotherapy. University of Lethbridge Theses (Alberta, Canada). http://opus.uleth.ca/handle/10133/5700. accessed Dec 15, 2020. 
24. Greene RF, Collins JM, Jenkins JF, Speyer JL, Myers CE. Plasma pharmacokinetics of adriamycin and adriamycinol: implications for the design of in vitro experiments and treatment protocols. Cancer Res. 1983;43:3417-21.

25. Menozzi M, Valentini L, Vannini E, Arcamone F. Self-association of doxorubicin and related compounds in aqueous solution. Pharm. Sci. 1984;73:766-70.

26. Raijmakers R, Speth $P$, de Witte T, Linssen P, Wessels J, Haanen C. Infusion-rate independent cellular adriamycin concentrations and cytotoxicity to human bone marrow clonogenic cells (CFU-GM). Br J Cancer. 1987;56:123-6.

27. Bates DA, Fung H, Mackillop WJ. Adriamycin uptake, intracellular binding and cytotoxicity in Chinese hamster ovary cells. Cancer Lett. 1985;28:213-21.

28. Anand R, Ottani S, Manoli F, Manet I, Monti S. A close-up on doxorubicin binding to Y-cyclodextrin: an elucidating spectroscopic, photophysical and conformational study.RSC Adv. 2012; 2:2346-57.

29. Kaushik D, Bansal G. Four new degradation products of doxorubicin: An application of forced degradation study and hyphenated chromatographic techniques. J Pharm Anal. 2015;5:285-95.

30. Morrison JD, Schlager CK, Lee AE, van Breemen RB, Gaba RC. Does doxorubicin survive thermal ablation? Results of an ex vivo bench top study. Diagn Interv Radiol. 2018;24:28-30.

31. Wirtschafter JD. Clinical doxorubicin chemomyectomy: An experimental treatment for benign essential blepharospasm and hemifacial spasm. Ophthalmology. 1991;98:357-66.

32. Shan H, Cao Z, Chi C, Wang J, Wang X, Tian J, et al. Advances in Drug Delivery via Biodegradable Ureteral Stent for the Treatment of Upper Tract Urothelial Carcinoma. Front Pharmacol. 2020;11:224. doi:10.3389/fphar.2020.00224

33. Masquelier M, Vitols S. Drastic effect of cell density on the cytotoxicity of daunorubicin and cytosine arabinoside. Biochem Pharmacol. 2004;67:1639-46

34. Bogason A, Quartino AL, Lafolie P. Masquelier M, Karlsson MO, Paul C. et al. Inverse relationship between leukaemic cell burden and plasma concentrations of daunorubicin in patients with acute myeloid leukaemia. Br J Clin Pharmacol. 2011;71:514-21.

35. Pisco AO, Huang S. Non-genetic cancer cell plasticity and therapy-induced stemness in tumour relapse: 'What does not kill me strengthens me'. Br J Cancer. 2015;112:1725-32.

36. Lankelma J, Dekker H, Luque FR, Luykx S, Hoekman K, van derValk, at al. Doxorubicin gradients in human breast cancer. Clin Cancer Res. 1999;5:1703-07.

37. Saggar JK, Tannock IF. Activity of the hypoxia-activated pro-drug TH-302 in hypoxic and perivascular regions of solid tumors and its potential to enhance therapeutic effects of chemotherapy. Int J Cancer. 2014;134:2726-34.

38. Parker AL, Cox TR. The role of the ECM in lung cancer dormancy and outgrowth. Front Oncol. 2020;10:1766. doi: 10.3389/fonc.2020.01766.

39. Siemann D.W. The unique characteristics of tumor vasculature and preclinical evidence for its selective disruption by tumor-vascular disrupting agents. Cancer Treat Rev. 2011; 37: 63-74. 
40. Chang J, Bhasin SS, Bielenberg DR, Sukhatme VP, Bhasin M, Huang S, et al. Chemotherapy-generated cell debris stimulates colon carcinoma tumor growth via osteopontin. FASEB J. 2019;33:114-25.

41. Garnick, M., Israel, M., Khetarpal, V. \& Luce, J. Persistence of anthracycline levels following dermal and subcutaneous adriamycin extravasation. Proc Am Assoc Cancer Res 1981,4:96-9.

42. Speth PA, Linssen PC, Holdrinet RS, Haanen C. Plasma and cellular adriamycin concentrations in patients with myeloma treated with ninety-six-hour continuous infusion. Clin Pharmacol Ther. 1987;41:661-5.

\section{Tables}

Table 1. Characterization of SL2 lymphoma cells used in two step dormancy/recurrence (TSDR) model.

\begin{tabular}{|c|c|}
\hline Specific aspect & SL2 cell line used in TSDR model \\
\hline Origin, ploidy & $\begin{array}{l}\text { Spontaneous lymphoma developed in DBA/2 mice, } \\
\text { diploid }\end{array}$ \\
\hline $\begin{array}{l}\text { Morphology (May-Grunwald stained slides } \\
\text { and confocal microscopy) }\end{array}$ & $\begin{array}{l}\text { Rounded } 10-12 \mu \mathrm{m} \text { in diameter, basophilic cytoplasm, } \\
\text { moderately granular chromatin, } \mathrm{N} / \mathrm{C} \text { ratio }=0.69-0.74\end{array}$ \\
\hline Growth characteristics in vitro and in vivo & $\begin{array}{l}\text { Suspension in vitro. Ascites and solid tumor in } \\
\text { DBA/2 or RAG2 } 2^{-1-} \text { mice }\end{array}$ \\
\hline Immunophenotype & $\mathrm{CD}^{+} 4^{-} 8 \mathrm{a}^{+} 44^{+} 45^{+}$ \\
\hline $\begin{array}{l}\text { Mean survival time of DBA/2 mice with } \\
\text { ascites tumor following i.p. implantation of } \\
5 \times 10^{5} \text { cells on day } 0\end{array}$ & $18 \pm 2.1$ days \\
\hline Invasiveness, metastasis & $\begin{array}{l}\text { Penetrating abdominal wall with subsequent ascites } \\
\text { after s.c. implantation; metastatic deposits in serous } \\
\text { cavities and lungs. }\end{array}$ \\
\hline $\begin{array}{l}\text { Sensitivity to dox (administered as a single } \\
\text { i.v. } 15 \mathrm{mg} / \mathrm{kg} \text { push) in ascites tumor of } \\
5 \times 10^{4} \text { cells implanted on day } 0 .\end{array}$ & $\begin{array}{l}\text { Cure if injected during first } 24 \mathrm{~h} \text { of implantation; } \\
\text { growth retardation and recurrence if injected on days } \\
2-7 ; \text { no effect if injected on day } 8 \text { or later; }\end{array}$ \\
\hline $\begin{array}{l}\text { "Concomitant immunity" (solid tumor), } \\
\text { host cell infiltration into tumor }\end{array}$ & $\begin{array}{l}\text { Occurrence if two identical tumors are implanted two } \\
\text { or more days apart }\end{array}$ \\
\hline \multirow{2}{*}{$\begin{array}{l}\text { Granulo-monocytosis in blood (tumor } \\
\text { bearing mice on day } 7 \text { ) }\end{array}$} & Granulocyte count $>2.8$ fold increase \\
\hline & Monocyte count $>2.1$. fold increase \\
\hline
\end{tabular}

\section{Table 2. Summary and comparison of doxorubicin and its modification - degraded dox used in TSDR model.}




\begin{tabular}{|c|c|c|}
\hline Parameter & Dox & Dox-dgr \\
\hline $\begin{array}{l}\text { Fluorescence spectra in aqueous solutions } \\
\text { (PBS diluted samples) }\end{array}$ & $\begin{array}{l}\text { Three peaks at } \\
\text { around } 560,594 \\
\text { and } 638 \mathrm{~nm}\end{array}$ & $\begin{array}{l}\text { Three peaks at around } 560 \text {, } \\
594 \text { and } 638 \mathrm{~nm}\end{array}$ \\
\hline $\begin{array}{l}\text { Fluorescence intensity in aqueous solutions } \\
\text { (PBS diluted samples, fresh dox=1) }\end{array}$ & 1 & 0.003 \\
\hline $\begin{array}{l}\text { Fluorescence spectra in nucleus of viable or } \\
\text { dead/apoptotic cells (confocal images, } 488 \\
\text { nm excitation) }\end{array}$ & $\begin{array}{l}\text { Two peaks at } \\
\text { around } 600 \text { and } \\
660 \mathrm{~nm}\end{array}$ & $\begin{array}{l}\text { Two peaks at around } 600 \text { and } \\
660 \mathrm{~nm}\end{array}$ \\
\hline $\begin{array}{l}\text { Fluorescence intensity in nucleus of viable } \\
\text { cells (confocal images, } 488 \mathrm{~nm} \text { excitation, } \\
\text { fresh dox=1) }\end{array}$ & 1 & 0.07 \\
\hline $\begin{array}{l}\text { Fluorescence intensity in nucleus of } \\
\text { dead/apoptotic cells (confocal images, } 488 \\
\text { nm excitation) }\end{array}$ & 1 & 0.2 \\
\hline $\begin{array}{l}\text { Ratio of nuclear/cytoplasmic fluorescence in } \\
\text { viable SL2 cells (ROI area integral) }\end{array}$ & $19.0: 1$ & $2.1: 1$ \\
\hline $\begin{array}{l}\text { Absorbance spectra in aqueous solutions } \\
\text { (PBS diluted samples). Dox-dgr ascribed in } \\
\text { comparison to dox. }\end{array}$ & $\begin{array}{l}\text { Typical one band } \\
\text { at around } 490 \mathrm{~nm}\end{array}$ & $\begin{array}{l}\text { Hypochromism between } 415 \\
\text { and } 540 \mathrm{~nm} \text {, hyperchromism } \\
\text { above } 540 \mathrm{~nm}\end{array}$ \\
\hline $\begin{array}{l}\text { HPLC analysis (internal standard - } \\
\text { daunorubicin hydrochloride) }\end{array}$ & $\begin{array}{l}\text { Retention time } \\
11.1 \mathrm{~min}\end{array}$ & $\begin{array}{l}\text { Retention time } 11.1 \text { min., } \\
\text { byproducts }\end{array}$ \\
\hline $\begin{array}{l}\text { Physical appearance (aqueous solution in } \\
\text { original vial } 2 \mathrm{mg} / \mathrm{ml} \text { ). }\end{array}$ & $\begin{array}{l}\text { Yellow-orange } \\
\text { color }\end{array}$ & $\begin{array}{l}\text { Dark red-brown color, sediment } \\
\text { formation }\end{array}$ \\
\hline $\begin{array}{l}\text { Antiproliferative capacity as a WBC nadir in } \\
\text { blood } 48 \mathrm{hr} \text { following i.v. injection of } 15 \\
\mathrm{mg} / \mathrm{kg}\end{array}$ & $\begin{array}{l}\text { WBC decrease } \approx 3 \\
\text { fold }\end{array}$ & No effect- \\
\hline $\begin{array}{l}\text { Therapeutic efficacy in SL2 bearing mice } \\
\text { (day } 1 \mathrm{after} 5 \times 10^{4} \text { cell implantation) injected } \\
\text { i.v. } 15 \mathrm{mg} / \mathrm{kg}\end{array}$ & $\begin{array}{l}\text { Cure ( }>60 \text { days } \\
\text { survival) }\end{array}$ & No effect \\
\hline $\begin{array}{l}\text { Growth and "recurrence" in TSDR model (10 } \\
\mu \mathrm{g} / \mathrm{ml} \text { drug loading dose) }\end{array}$ & No & Yes, the same as control \\
\hline
\end{tabular}

\section{Figures}




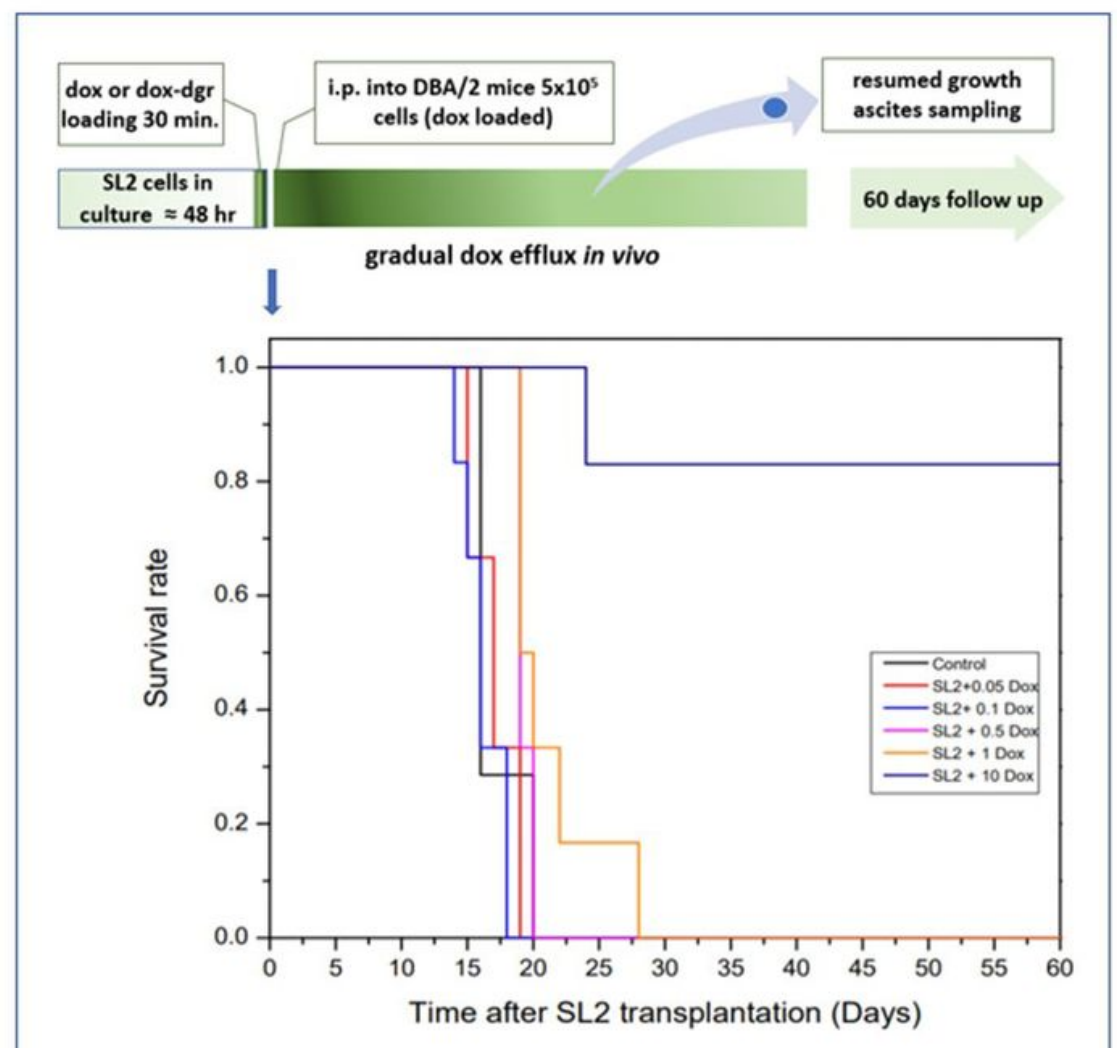

\section{Figure 1}

Design of two step (in vitro-in vivo) dormancy/recurrence model and selection of an optimal exposure dose. TSDR model of a lymphoma cell dormancy explored Dox pre-loaded SL2 cells injected i.p. into intact DBA/2 mice. Surviving fraction of DBA/2 mice after i.p. injection of $5 \times 105$ SL2 cells pre-exposed in vitro with dox for $30 \mathrm{~min}$. The $10 \mu \mathrm{g} / \mathrm{ml}$ of dox exposure was sufficient enough to result in sustainable tumor growth suppression. 


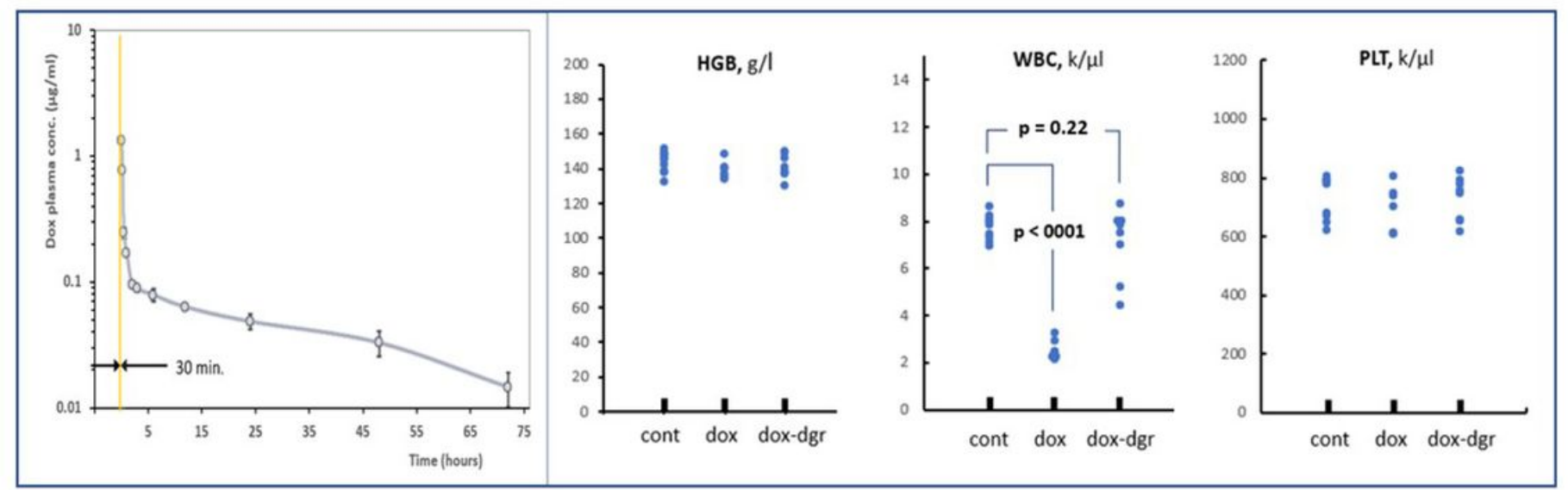

Figure 2

Plasma dox pharmacokinetics and antiproliferative capacity (WBC nadir) of drug at $48 \mathrm{hr}$ following 15 $\mathrm{mg} / \mathrm{kg}$ injection. Plasma dox concentration was below the $10 \mu \mathrm{g} / \mathrm{ml}$ dox exposure concentration used in our TSDR model for cell loading. The absence of antiproliferative myelotoxic effects of dox-dgr in the 48 $\mathrm{h}$ WBC nadir test caused results to differ significantly in comparison to fresh dox effects tested under the same conditions. 


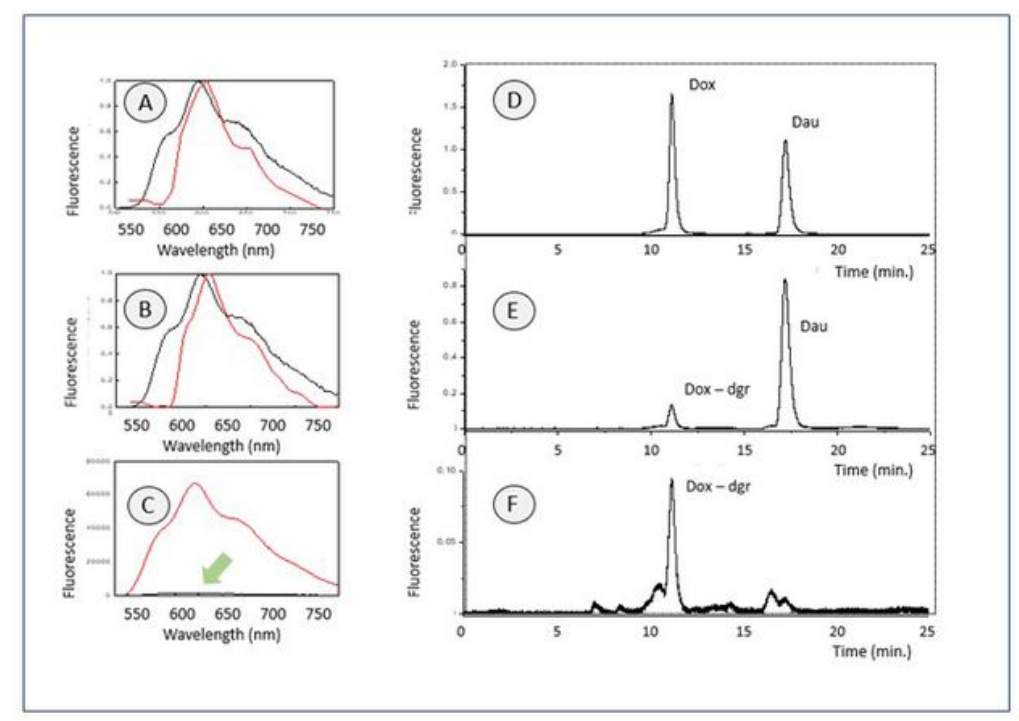

\section{Figure 3}

Comparison of fluorescence spectra and HPLC analysis of dox and dox-dgr. Dox (A panel) and dox-dgr (B panel) present fluorescence spectra of a drug in aqueous solution (red line) and in the nucleus of drug loaded cells (black line). Comparison of the intensity of fluorescence (C panel) between dox (red line) and dox-dgr (black line-arrow) in aqueous solution. HPLC chromatograms for fresh dox (D) and 37 0C 120 days degraded dox-dgr (E and F). Retention times of dox and internal standard (daunorubicin) were about 11.1 and $17.2 \mathrm{~min}$, respectively. To better visualize the presence of byproducts daunorubicin was not added to a sample shown in panel $\mathrm{F}$. 


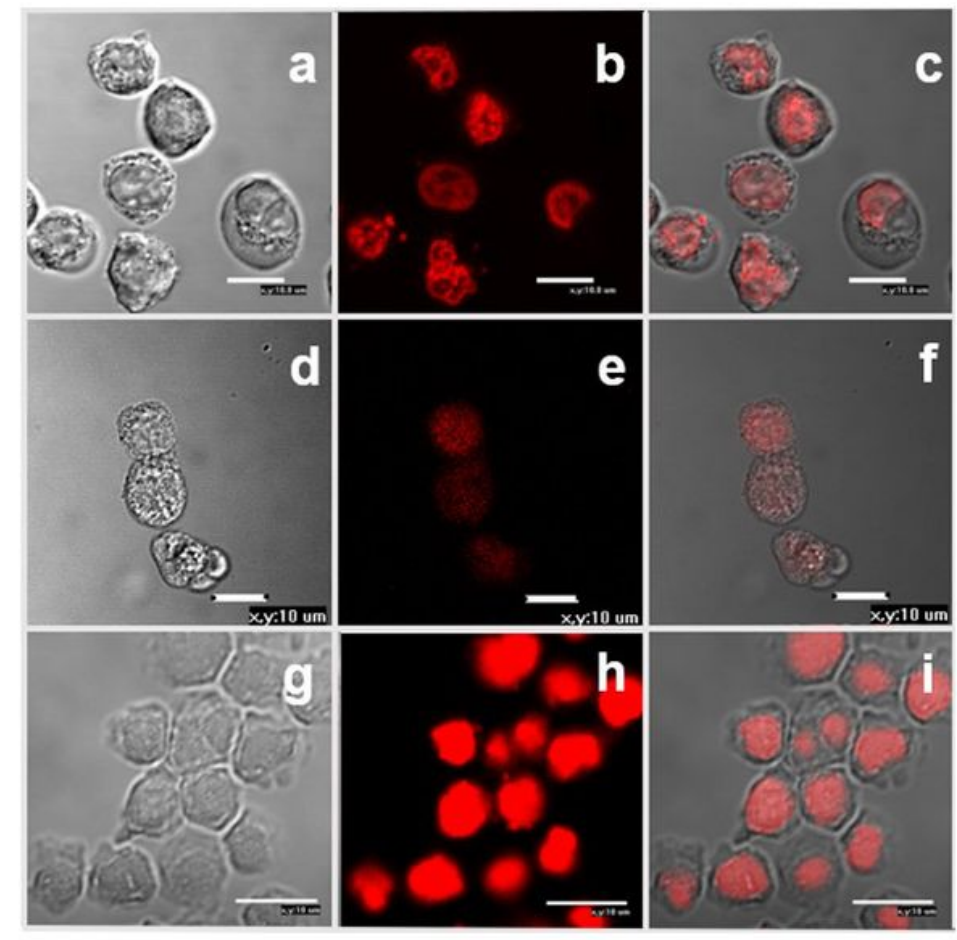

\section{Figure 4}

Intracellular dox and dox-dgr fluorescence patterns following in vitro cell drug load on day 0 before injection into DBA/2 mice (confocal microscope images). Brightfield ( $a, d, g)$, fluorescence $(b, e, h)$ and merged (c, f, i) images following incubation of SL2 suspension with $10 \mu \mathrm{g} / \mathrm{ml}$ of dox (ac) or dox-dgr (d-f and $\mathrm{g}-\mathrm{i}$ ). Nuclear fluorescence intensity was $\sim 14$ times higher in dox loaded cells as compared to dox-dgr loaded cells. Some SL2 cell clusters were exhibiting loss of membrane integrity ( $\mathrm{g}-\mathrm{i})$ and were intensely accumulating dox-dgr in the nucleus.

\section{Supplementary Files}

This is a list of supplementary files associated with this preprint. Click to download.

- ZaleskisG.BMCdormancysupplementarymaterial.pdf 